\title{
In Vitro Characterization and In Vivo Properties of Salmonellae Lytic Bacteriophages Isolated from Free-Range Layers
}

Author(s)

Fiorentin $\mathrm{L}^{1}$

Vieira ND ${ }^{1}$

Barioni Júnior W

Barros $S^{2}$

Embrapa Suínos e Aves

2 Laboratório Regional de Diagnóstico - UFPEL, Pelotas, RS

\section{Mail Address}

Laurimar Fiorentin

Embrapa Suínos e Aves

BR 153 Km 110, Caixa Postal 21

89.700-000 - Concórdia, SC.

Phone 0xx49 442-8555

Fax $\quad 0 x x 49442-8559$

E-mail: laurimar@cnpsa.embrapa.br

\section{Keywords}

Bacteriophages, food poisoning, poultry salmonella.

\section{ABSTRACT}

Occurrence of food poisoning related to Salmonella-contaminated eggs and chicken meat has been frequent in humans. Salmonella Enteritidis (SE) and Salmonella Typhimurium (ST) are included among the most important paratyphoid salmonellae associated with chicken meat and eggs. Elimination of Salmonella at the pre-harvest stage can play a significant role in preventing the introduction of this pathogen into the food chain and consequently in the reduction of food poisoning in humans. Bactericidal bacteriophages may provide a natural, nontoxic, feasible and non-expensive component of the multi-factorial approach for a pre-harvest control of Salmonella in poultry. Five bacteriophages lytic for SE PT4 and ST were obtained from 107 samples of feces of freerange layers in Brazil. All bacteriophages were characterized in vitro and in vivo, showing head and tail morphology and dsDNA as nucleic acids. Results of in vivo studies suggested that bacteriophages do not remain in Salmonella-free birds longer than one day, whereas they multiply in Salmonella-infected birds for longer periods. Besides, selection for phageresistant SE PT4 did not seem to occur in the short term. Isolated bacteriophages will be investigated for their potential for pre-harvest biocontrol of SE PT4 in poultry.

\section{INTRODUCTION}

Occurrence of food poisoning related to Salmonella-contaminated eggs and chicken meat has been frequent in humans. Food poisoning caused by Salmonella results in reduction of productivity, discomfort, expenditures with medication and eventually death (Persson \& Jendteg, 1992; Mead et al., 1999). Eating raw or undercooked eggs has also been considered a major risk factor for food poisoning with salmonellae in some situations (Molback \& Neiman, 2002). Salmonella Enteritidis (SE) (Tavechio et al., 2002; Chung et al., 2003) and Salmonella Typhimurium (ST) (Flensburg 1999; Taunay et al., 1996) figure among the most important paratyphoid salmonellae associated with chicken meat and eggs.

SE is the most frequently isolated Salmonella from poultry products in Brazil. Santos et al. (2000) reported up to $53.5 \%$ of frozen broilers as being contaminated by Salmonella, so that SE represented $60 \%$ of total isolates and dos Santos et al. (2003) reported that $57.65 \%$ of SE isolated in Brazil were of phage type 4 (SE PT4). Between 1993 and 1997, Laboratory I from Instituto Adolfo Lutz (São José do Rio Preto, São Paulo, Brazil) identified that raw eggs were involved in $95.7 \%$ of all food poisoning cases caused by SE PT4 (Paresi et al., 1998). SE was also the most prevalent; it represented $32.7 \%$ of 4,581 Salmonella strains isolated from non-human sources since January 1996 until December 2000, at Instituto Adolfo Lutz, São Paulo, Brazil (Tavechio et al., 2002). On the 
Fiorentin L, Vieira ND, Barioni Júnior W, Barros S other hand, the percentage of ST isolation in food poisoning cases decreased from $77 \%$ in the 1970's to $36 \%$ in the 1980's (Taunay et al., 1996). However, the occurrence of ST in poultry products in Brazil and other countries (Flensburg, 1999) still demands efforts of the poultry industry to reduce its occurrence.

Elimination of Salmonella at the pre-harvest stage can play a significant role in preventing the introduction of this pathogen into the food chain and consequently in the reduction of food poisoning in humans (Wegener et al., 2003). Pre-harvest control of Salmonella is more likely to be effective through a multi-factorial approach. Good agricultural practices such as hazard analysis and critical control point (HACCP) (Rose et al., 2002; Nayak et al., 2003), vaccination (Cogan \& Humphrey, 2003; Zhang-Barber et al., 1999; Yamame et al., 2000), probiotics, prebiotics and synbiotics (Van Immerseel et al., 2002) have been used as preventive measures when Salmonella infection is likely to occur. However, the use of anti-microbial drugs many times is still required when other measures are not efficient enough (Davies et al., 2003; Fernadez et al., 2001). In such cases, a new concern may arise due to the selection of resistant bacteria (Chung et al., 2003; Molbak et al., 2002; Velonakis et al., 2001) or the possibility that drug residues remain in meat and eggs consumed by humans (Donoghue, 2003).

In order to reduce the use of anti-microbial drugs, new methods for Salmonella control within the poultry production are required to be used in conjunction with good agricultural practices. These methods must be efficient in reducing Salmonella contamination on the final product without increasing production costs or introducing risks of chemical contamination of poultry products. Bactericidal bacteriophages may provide a natural, nontoxic, feasible and non-expensive component of the multi-factorial approach for a preharvest control of Salmonella in poultry. In this study, bacteriophages were isolated using SE PT4 and ST as bacterial targets and were evaluated for morphology and ability to lyse cultures in vitro. Unique profiles of DNA amplification were identified. Three bacteriophages were administered to SE-infected and non-infected Specific Pathogen Free (SPF) chickens to study the dynamics of their excretion.

\section{MATERIAL E METHODS}

\section{Bacterial strains}

SE PT4 isolate P125589 was kindly provided by Dr Paul Barrow, from the ARFC Institute for Animal Health,
In Vitro Characterization and In Vivo Properties of Salmonellae Lytic Bacteriophages Isolated from FreeRange Layers

Houghton Laboratory, Cambridge, England (Barrow \& Lovell, 1991). Dr B. Rowe originally obtained this isolate from a case of human food poisoning at the Central Public Health Laboratory, London, UK. ST was purchased from the American Type Tissue Collection (Manassas, Virginia, USA), where it is deposited under the number 14028 as Salmonella choleraesuis subsp. choleraesuis serotype Typhimurium. Salmonellae were cultivated in Nutrient Agar or Broth (NA or NB, $1 \mathrm{~g} / \mathrm{L}$ beef extract, $2 \mathrm{~g} / \mathrm{L}$ yeast extract, $5 \mathrm{~g} / \mathrm{L}$ peptone, $5 \mathrm{~g} / \mathrm{L}$ sodium chloride, and $15 \mathrm{~g} / \mathrm{L}$ bacteriologic agar for solid media) and kept frozen at $-80^{\circ} \mathrm{C}$ unless stated.

\section{Bacteriophage isolation from feces.}

A total of 107 feces samples from individuals of different avian species (Table 1) were collected from the ground and subjected to bacteriophage isolation under the technique described by Kudva et al. (1999). Briefly, one gram of feces was inoculated into $10 \mathrm{~mL}$ of a log phase SE PT4 or ST culture grown in nutrient broth added with $5 \mathrm{mM} \mathrm{MgSO}_{4}\left(\mathrm{NB}-\mathrm{MgSO}_{4}\right)$. This mixture was incubated for approximately 18 hours at $37^{\circ} \mathrm{C}$ under shaking (200rpm) and treated with $5 \%$ chloroform to lyse the bacteria. The preparation was centrifuged $(12,000 \times \mathrm{g}$ for 5 minutes) and $10 \mu \mathrm{L}$ of supernatant was applied onto an overlay culture of Salmonella. Overlays were prepared by inoculation of $250 \mathrm{~mL}$ of a Salmonella culture in exponential growth into $7 \mathrm{~mL}$ of melted NB $\left(45^{\circ} \mathrm{C}\right)$ containing $0.7 \%$ agarose. The melted agarose containing the bacteria was laid over a $10 \mathrm{~cm}-$ diameter sterile Petri dish with nutrient agar and incubated for 24 hours at $37^{\circ} \mathrm{C}$ after solidification. The plaques of inhibition of Salmonella growth on the agarose layer, corresponding to lyse caused by bacteriophages, were cut for cloning.

\begin{tabular}{|c|c|c|}
\hline Birds & Samples & Location \\
\hline Free range layers & 40 & Concórdia, SC, Brazil \\
\hline Broiler breeders & 45 & Concórdia, SC, Brazil \\
\hline Rhea & 13 & Venâncio Aires, RS, Brazil \\
\hline Caged songbirds & 9 pools & Concórdia, SC, Brazil \\
\hline Total & 107 & - \\
\hline
\end{tabular}

The cut agarose was vortexed and diluted tenfold in $\mathrm{SM}$ buffer $\left(5.8 \mathrm{~g} / \mathrm{L} \mathrm{NaCl}, 2 \mathrm{~g} / \mathrm{L} \mathrm{MgSO}_{4} .7 \mathrm{H}_{2} \mathrm{O}, 0.05 \mathrm{M}\right.$ Tris-

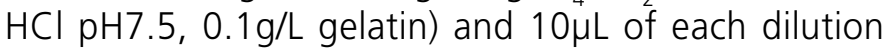
were inoculated into $250 \mathrm{~mL}$ of a log phase Salmonella culture. After 20 minutes at $37^{\circ} \mathrm{C}$, it was inoculated into $7 \mathrm{~mL}$ of NB with $0.7 \%$ agarose and overlay cultures 
Fiorentin L, Vieira ND, Barioni Júnior W, Barros S were prepared as described above. This procedure was repeated three times with isolated plaques to purify the cultures. Final clones were named, amplified on $50 \mathrm{~mL}$ of a log-phase Salmonella culture and stored at $80^{\circ} \mathrm{C}$ in SM buffer with 7\% Dimethyl Sulfoxide (DMSO) and $1 \%$ chloroform or at $4^{\circ} \mathrm{C}$ as a supernatant containing $1 \%$ chloroform.

\section{Salmonella isolation}

One gram of feces was inoculated into $9 \mathrm{~mL}$ of Rappaport-Vassiliadis Soya Peptone broth (RVS, 4.5g/L soya peptone, $7.2 \mathrm{~g}$ sodium chloride, $1.26 \mathrm{~g} / \mathrm{L}$ potassium dihydrogen phosphate, $0.18 \mathrm{~g} / \mathrm{L}$ di-potassium hydrogen phosphate, $13.58 \mathrm{~g} / \mathrm{L}$ magnesium chloride anhydrous, $0.036 \mathrm{~g} / \mathrm{L}$ malachite green, $\mathrm{pH} 5.2$ ) and incubated at $42^{\circ} \mathrm{C}$ for 24 hours. A loopful was then transferred to Brilliant Green Agar plates (BGA, 10g/L proteose peptone, $3 \mathrm{~g} / \mathrm{L}$ yeast extract, $10 \mathrm{~g} / \mathrm{L}$ lactose, $10 \mathrm{~g} / \mathrm{L}$ sucrose, $5 \mathrm{~g} / \mathrm{L}$ sodium chloride, $0.08 \mathrm{~g} / \mathrm{L}$ phenol red, $0.0125 \mathrm{~g} / \mathrm{L}$ brilliant green, $12 \mathrm{~g} / \mathrm{L}$ bacteriologic agar, $\mathrm{pH}$ 6.9) and incubated at $37^{\circ} \mathrm{C}$ for 48 hours. Light pinkwhite opaque colonies surrounded by red medium were tested by agglutination with polyvalent anti-somatic serum.

\section{Lytic capability}

Capacity of lysis was assessed for all bacteriophages using routine test dilution (RTD). Bacteriophage stocks were logarithmically diluted tenfold and aliquots of $50 \mathrm{\mu L}$ dropped onto ST or SE PT4 overlay cultures immediately after agarose solidification and incubated at $37^{\circ} \mathrm{C}$ for 24 hours. The highest dilution that caused confluent lysis of bacteria on the Salmonella overlay was recorded and compared among the different bacteriophages.

\section{Electron microscopy}

Electron microscopy was performed with standard techniques (Hayat, 1989) on bacteriophage-inoculated Salmonella cultures. Each bacteriophage was inoculated from fresh stocks into $1.5 \mathrm{~mL}$ of a log phase culture of the same Salmonella used for its isolation and the culture kept for 6 hours at $37^{\circ} \mathrm{C}$ under shaking (200rpm). Bacteriophage infected-bacteria were collected by centrifugation $(12,000 \mathrm{Xg}$ for 5 minutes) and the pellet was embedded in $100 \mu \mathrm{L}$ of $4 \%$ agarose. The pellet was cut in small fragments and fixed in $2 \%$ glutaraldehyde- $2 \%$ paraformaldehyde in $0.1 \mathrm{M}$ cacodylate buffer (pH7.4), postfixed in osmium tetroxide, dehydrated in ascending series of ethanol and embedded in Epon 812. Ultrathin sections were stained with uranil acetate and lead citrate and examined using
In Vitro Characterization and In Vivo Properties of Salmonellae Lytic Bacteriophages Isolated from FreeRange Layers

an EM 109 Zeiss transmission electron microscope at $80 \mathrm{~kW}$.

\section{DNA analysis}

Bacteriophages were produced in large scale by inoculating overlay cultures prepared on four $15 \mathrm{~cm}-$ diameter Petri dishes. Inoculations were performed to yield confluent plaques after incubation for 24 hours at $37^{\circ} \mathrm{C}$. Bacteriophage particles were collected by overnight diffusion into $50 \mathrm{~mL}$ of SM buffer laid on top of agarose, which was treated with $5 \%$ chloroform and centrifuged $\left(12,000 \times \mathrm{g}\right.$ for 10 minutes at $\left.4^{\circ} \mathrm{C}\right)$ to remove bacterial debris. Bacterial nucleic acids were removed by digestion with $1 \mathrm{mg} / \mathrm{mL}$ of DNAse 1 and RNAse A for three hours at $37^{\circ} \mathrm{C}$. Bacteriophages were then precipitated overnight at $4^{\circ} \mathrm{C}$ with $2 \%$ PEG 8000 and $2.5 \mathrm{M}$ sodium chloride and collected by centrifugation $\left(12,000 \times \mathrm{g}\right.$ for 15 minutes at $\left.4^{\circ} \mathrm{C}\right)$ (Helms et al., 1987). Bacteriophage nucleic acids were purified by standard phenol extraction and ethanol precipitation (Sambrook et al., 1989) and used for nuclease digestion tests or Random Amplified Polymorphic DNA Analyses (RAPD).

Approximately one microgram of bacteriophage nucleic acids were reacted for one hour at $37^{\circ} \mathrm{C}$ with 5IU of DNAse 1, Nuclease S1 or RNAse A diluted in appropriate buffers. Reacted nucleic acids were subjected to electrophoresis (110V/1:30h) in 1\% agarose in TE buffer $(10 \mathrm{mM}$ Tris- $\mathrm{HCl}, 1 \mathrm{mM}$ EDTA, $\mathrm{pH7.5)}$ gels stained with ethidium bromide $(10 \mathrm{mg} / \mathrm{mL})$ to identify possible degradation caused by the enzymes.

RAPD was performed with the "Ready-To-Go RAPD Analysis Beads" (Amersham Pharmacia Biotech) with all six primers in individual reactions. Amplification was standardized with $25 \mathrm{ng}$ DNA and $25 \mathrm{pmol}$ primers added to the components present in the reaction tube and a final volume of $25 \mathrm{~mL}$. Reactions were performed with 45 cycles of $95^{\circ} \mathrm{C}$ for one minute, $36^{\circ} \mathrm{C}$ for one minute and $72^{\circ} \mathrm{C}$ for two minutes. Amplified fragments were separated on $2 \%$ agarose gels electrophoresis as described above.

\section{In vivo bacteriophage properties}

The three bacteriophages denominated CNPSA1, CNPSA3 and CNPSA4 (Table 2) were selected and administered to birds because their RAPD profiles indicated they were distinct viruses. Three groups with seven specific pathogen free (SPF) chickens (SPAFAS, Charles River Laboratories) were housed in isolator cabinets with filtered air from one until 16 days of age. Group 1 was orally infected at the third day of age 
Fiorentin L, Vieira ND, Barioni Júnior W, Barros S with $10^{3}$ colony-forming units (CFU) of SE PT4 per bird. Two days later, each bird of Group 1 was orally inoculated with a pool of $10^{5}$ plaque forming units (PFU) of each phage. Group 2 was inoculated only with bacteriophages, at the same dose, and Group 3 was kept as uninfected control (Table 3).

\begin{tabular}{lcc}
\hline \multicolumn{2}{c}{ Table 2 - Isolated bacteriophages. } \\
Bacteriophage & Origin of feces & $\begin{array}{c}\text { Bacterium used } \\
\text { as a target }\end{array}$ \\
CNPSA 1 & Free range layer, Concórdia, SC & SE PT4 \\
CNPSA 2 & Free range layer, Concórdia, SC & ST \\
CNPSA 3 & Free range layer, Concórdia, SC & ST \\
CNPSA 4 & Free range layer, Concórdia, SC & ST \\
CNPSA 5 & Pool of captive songbirds, Concórdia, SC & ST \\
\hline
\end{tabular}

$\begin{aligned} & \text { Table 3 } \\
& \text { isolates. }\end{aligned}$
\begin{tabular}{lccc} 
Group & Birds & SE PT4 per bird & Bacteriophages \\
1 & 7 & $10^{3}$ CFU at the $3^{\text {rd }}$ day & $10^{5} \mathrm{PFU}$ at the $5^{\text {th }}$ day \\
2 & 7 & None & $10^{5} \mathrm{PFU}$ at the $5^{\text {th }}$ day \\
3 & 7 & None & None \\
\hline
\end{tabular}

Cloacal swabs were collected daily for SE PT4 and bacteriophage isolation. Salmonella was isolated by incubating swabs overnight at $42^{\circ} \mathrm{C}$ in $3 \mathrm{~mL}$ of RVS, followed by loopful inoculations on BGA and incubation at $37^{\circ} \mathrm{C}$ for 48 hours. Identification of Salmonella was carried out by colony morphology and serum agglutination as described above. Bacteriophages were isolated by incubating swabs at $37^{\circ} \mathrm{C}$ in one milliliter of an exponential-phase culture of SE PT4. After treatment with $5 \%$ chloroform and centrifugation $(12,000 \times \mathrm{g}$ for 5 minutes), $5 \mu \mathrm{L}$ of the supernatant were inoculated onto a overlay of SE PT4 grown on NB-MgSO solidified with $0.7 \%$ agarose. Presence of bacteriophages was identified by transparency of the bacterial overlay on sample sites.

At the 16th day of life, all birds were necropsied and attempts were made to isolate SE PT4 and bacteriophages from the ceca, spleen and liver of every bird. Fragments of tissue used for Salmonella isolation were inoculated in $3 \mathrm{~mL}$ of RVS followed by inoculation in BGA as described above. Attempts to isolate bacteriophage were made with fragments of tissue cultivated in $1 \mathrm{~mL}$ of SE PT4 in exponential growth followed by treatment with $5 \%$ chloroform, centrifugation and inoculation of $10 \mu \mathrm{L}$ of supernatant onto bacterial overlays as described above.
In Vitro Characterization and In Vivo Properties of Salmonellae Lytic Bacteriophages Isolated from FreeRange Layers

Five isolates of Salmonella were obtained from the ceca of each bird from the group that was inoculated with SE PT4 and bacteriophage. Bacteriophage sensitivity was assessed for all isolates. Five microliters of each bacteriophage stock was applied onto a overlay of the Salmonella isolates grown on NB solidified with $0.7 \%$ agarose.

Cecal contents obtained at necropsy were weighed and logarithmically diluted tenfold in PBS pH7.2. Dilutions $(100 \mu \mathrm{L})$ were inoculated on BGA with Novobiocin $(40 \mu \mathrm{g} / \mathrm{mL})$ to obtain CFU/g.

\section{RESULTS AND DISCUSSION}

\section{Bacteriophage isolation}

Five bacteriophages were isolated from 107 (4.67\%) tested samples. Bacteriophages were denominated CNPSA1, CNPSA2, CNPSA3, CNPSA4, and CNPSA5, the letters stand for the name of the research institute and the number is the order of bacteriophage isolation. CNPSA5, which was isolated from captive birds, was the only bacteriophage obtained from a source other than free-range layers. Probably, the broad range of feed sources naturally available to free-range chickens and their freedom to move in a larger area had some influence in the success of bacteriophage isolation. Bacteriophages lytic to Salmonella have been isolated from sewage water and poultry litter (Berchieri Jr et al., 1991; Sklar et al., 2001), demonstrating their natural occurrence in the environment.

Bacteriophage CNPSA2 could not be recovered after a few weeks stored either at $4^{\circ} \mathrm{C}$ or $-80^{\circ} \mathrm{C}$ and was therefore not included in additional studies. It was not possible to identify a reason for the loss of viability, but once all bacteriophages were submitted to the same management same, it is more likely that it was related to the nature of CNPSA2 instead of laboratory handling.

All bacteriophages produced small clear and round plaques with well-defined edges and ranging from 1 to $1.5 \mathrm{~mm}$ of diameter, in both salmonellae tested. This is an indication that all bacteriophages are lytic, however the possibility that they have a lysogenic stage cannot be ruled out, once specific tests for lysogeny were not carried out.

\section{Salmonella isolation from field samples}

No Salmonella was isolated from the 107 feces samples. The fact that bacteriophage-positive feces were negative in attempts to isolate Salmonella cannot be fully explained. The feces were collected from the ground and may have been contaminated by 
Fiorentin L, Vieira ND, Barioni Júnior W, Barros $\mathbf{S}$
In Vitro Characterization and In Vivo Properties of Salmonellae Lytic Bacteriophages Isolated from FreeRange Layers bacteriophages from the environment. Also, all bacteriophages were isolated from samples obtained from adult free range chickens or captive songbirds, which are likely to be subjected to a mild Salmonella infection and therefore shed very low numbers of CFU in the feces (Asheg et al., 2001). Low shedding of Salmonella may not be detected in conventional bacteriologic tests due to overgrow of other bacteria when inoculated into RVS. Bacteriophages, however, last for longer periods in the environment and are eliminated in larger numbers. This makes bacteriophages more likely to be recovered when shed in the feces along with Salmonella, because they are amplified in the SE PT4 culture inoculated with feces.

\section{Lytic capability}

RTD assays demonstrated that all bacteriophages lyse both SE PT4 and ST at similar multiplicity of infection (MOI). Confluent lysis was obtained with bacteriophage stocks containing similar PFU titers diluted as high as $10^{-3}$ and $10^{-4}$ when $50 \mu \mathrm{L}$ were applied onto overlay cultures of either Salmonella. These results indicated that capacity of lysis in vitro could not be a criterium for selection of bacteriophages to be used in biocontrol of Salmonella. MOI also could not be used as a standard to express bacteriophage infectivity.

\section{Electron microscopy and DNA analysis}

All isolated bacteriophages showed similar head and tail ultrastructure (Figure 1) ranging from 80 to $120 \mathrm{~mm}$. Head and tail ultra-structure is a common feature of the morphology of bacteriophages (Levine, 1992). Some microscopy fields showed bacteriophages inside Salmonella cell debris (Figure 2), confirming their capacity to lyse Salmonella cells.

Bacteriophages were identified as dsDNA viruses in the assays carried out with bacteriophage nucleic acids and the different nucleases. Digestions with DNAse 1 caused degradation of nucleic acids while electrophoretograms showed that their nucleic acids reacted with Nuclease $S 1$, which cleaves ssDNA. Besides, treatment with RNAse A showed the expected bands of non-digested DNA. Families of tailed bacterial viruses with dsDNA are Myoviridae, Podoviridae and Siphoviridae (ICVT, 2003).

RAPD allowed differentiation of all bacteriophages but for CNPSA4 and CNPSA5 (Figure 3). Since only six primers were tested, we cannot rule out the possibility that these two isolates may actually represent different bacteriophages. In order not to test twice the same bacteriophage, CNPSA5 was not evaluated in vivo.

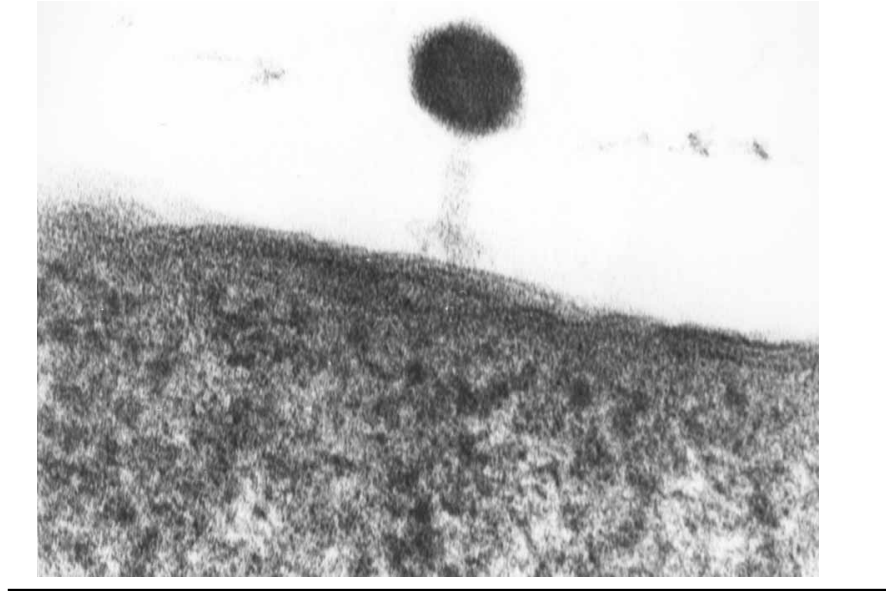

Figure 1 - Bacteriophage showing the characteristic ultra-structure of head and tail with tail fibers inserted into Salmonella Enteritidis membrane. 238,000x.

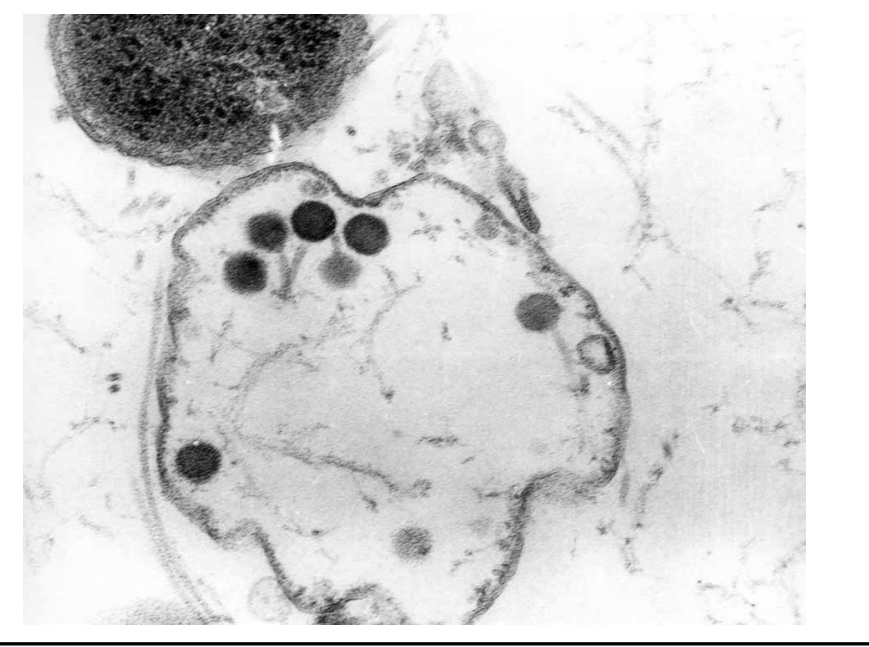

Figure 2 - Bacteriophage particles inside bacterial debris. $86,000 x$

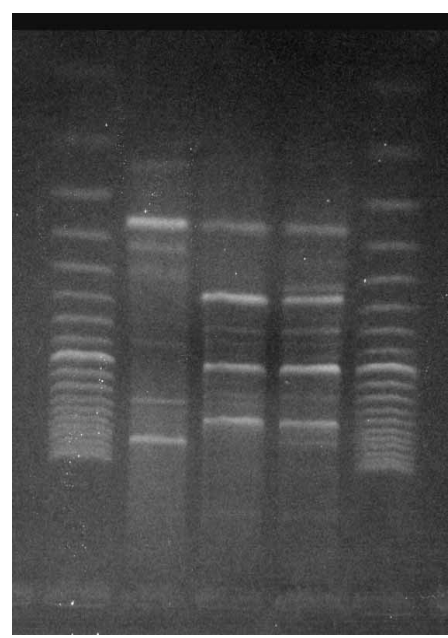

Figure 3 - RAPD profiles showing differences between bacteriophages used for in vivo characterization. Lanes from left to right: 100bp ladder, DNA of bacteriophages CNPSA1, CNPSA3, CNPSA4, CNPSA5, 100bp ladder. DNA of bacteriophages was amplified with the primer $5^{\prime}-\mathrm{d}[\mathrm{GGTGCGGGAA]-3'.} \mathrm{Bacterioph-}$ age CNPSA2 lost viability in the laboratory. 
Fiorentin L, Vieira ND, Barioni Júnior W, Barros S
RAPD proved to be a useful tool to check purity of cultures and to confirm identity of isolates in clinical trials.

\section{In vivo properties}

Cloacal swabs of control birds (Group 3) were negative for both bacteriophages and Salmonella throughout the experiment. Swabs collected from internal organs of control birds were also negative for both bacteriophages and Salmonella, confirming the negative status of the control group for Salmonella and the non-occurrence of bacteriophages either in the SPF chickens or in the feed used in the experiment.

SE PT4 uninfected-phage administered birds (Group 2) showed only one bacteriophage-positive cloacal swab out of seven swabs collected one day after bacteriophage administration, and all swabs were negative thereafter. All seven swabs of SE PT4 infectedphage administered chickens (Group 1) were positive for the presence of bacteriophage two days after administration, ranging between $4 / 7$ and $7 / 7$ thereafter (Figure 4).

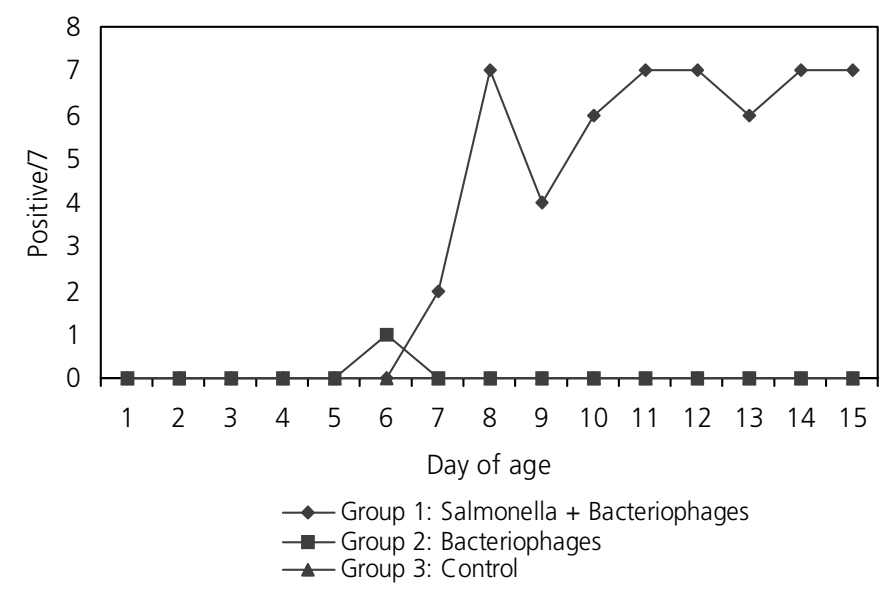

Figure 4. Frequency of bacteriophage isolation from cloacal swabs of SPF chickens inoculated at the $3^{\text {rd }}$ day of life with $10^{3}$ CFU of SE PT4.

It seems clear that bacteriophages need Salmonella in the alimentary tract to multiply. Negative results of bacteriophage isolations from birds of group 2 two days after inoculation indicates that no bacterium from the physiologic flora or other cell are targeted by these bacteriophages inside the alimentary tract of SPF birds. This observation characterizes the self-limiting nature of bacteriophages when inoculated in Salmonella-free birds.
In Vitro Characterization and In Vivo Properties of Salmonellae Lytic Bacteriophages Isolated from FreeRange Layers

All cecal contents of the birds from Group 1 were positive at necropsy for both Salmonella and bacteriophages. It was evident that Salmonella will not be cleared from the alimentary tract of SPF chickens by bacteriophages under the conditions used in the present experiment. However, reduction of CFU per gram of feces may occur and be useful in biocontrol of Salmonella in poultry. Persistence of SE PT4 in infected birds is common (Gast \& Holt, 1998) and fecal shedding may persist for several weeks after infections (Shivaprasad et al., 1990). No spleen or liver sample was positive for bacteriophage, even though they were Salmonella positive. Therefore, bacteriophages are unable to survive in internal tissues even if carried into the blood stream by bacteria, macrophages or other cells.

SE PT4 was isolated from spleen and ceca of all inoculated chickens. Cecal contents collected at necropsy showed a mean of $87.5 \pm 23.7 \times 10^{8} \mathrm{CFU}$ per gram. This is an indication of heavy infection on inoculated chickens, even though a moderate infection dose $\left(10^{3}\right.$ CFU/bird) was used (Asheg et al., 2001). Isolation from spleen and ceca also indicates that SPF chickens were heavily infected by SE PT4, once this bacterium is likely to be cleared from internal tissues after two weeks when infection is performed with low doses (Asheg et al., 2001; Kinde et al., 2000). The high Salmonella contents in ceca may be a reason why Salmonella was isolated from every swab even though bacteriophages were present. Establishment of infection before the complete development of the physiologic microbiota and the maintenance of birds within filtered air cabinets are the likely reasons of this high infection rate even though the infecting dose was moderate.

All 35 isolates of Salmonella obtained from cecal contents at necropsy of birds from Group 1 remained sensitive to lysis by the three phages indicating that resistance to bacteriophages is not likely to develop in vivo within short periods. Also, none of these colonies showed the rough morphology that is indicative of selection under bacteriophage pressure. Recovery of bacteriophage-resistant SE after treatment of chickens with bacteriophages has been reported (Sklar \& Joerger, 2001). Bacteriophage resistance may be related to specific viruses or experimental protocols.

\section{CONCLUSIONS}

The occurrence of bacteriophages lytic for SE PT4 and ST in free-range layers in Brazil can be demonstrated by culturing feces with susceptible Salmonella. The 
bacteriophages that are more likely to be isolated present dsDNA as nucleic acids and show head and tail ultrastructure.

Results of this study suggest that bacteriophages CNPSA 1, CNPSA 3 and CNPSA4 do not remain in Salmonella-free birds longer than one day, although they multiply in Salmonella-infected birds for longer periods. Selection for phage-resistant SE PT4 did not seem to occur within short periods.

\section{REFERENCES}

Asheg AA, Fedorova V, Pistl J, Levkut M, Revajova, V, Kolodzieyski L, Sevcikova Z, Pilipcinec E. Effect of low and high doses of Salmonella enteritidis PT4 on experimentally infected chicks. Folia Microbiologica (Praha) 2001; 46(5):459-462

Barrow PA, Lovell MA. Experimental infection of egg-laying hens with Salmonella enteritidis phage type 4. Avian Pathology 1991; 20:335-348.

Berchieri, A. Jr,, Lovell, M.A., Barrow, P.A.. The activity in the chicken alimentary tract of bacteriophages lytic for Salmonella typhimurium. Research Microbiology 1991; 142:541-549.

Cogan TA, Humphrey TJ. The rise and fall of Salmonella Enteritidis in the UK. Journal of Applied Microbiology 2003; 94 (Suppl):114S$119 \mathrm{~S}$.

Chung YH, Kim SY, Chang YH. Prevalence and antibiotic susceptibility of Salmonella isolated from foods in Korea from 1993 to 2001. Journal of Food Protection 2003; 66(7):1154-1157.

Davies R, Liebana E, Breslin M. Investigation of the distribution and control of Salmonella enterica serovar Enteritidis PT6 in layer breeding and egg production. Avian Pathology 2003; 32(3):225237.

dos Santos LR, do Nascimento VP, de Oliveira SD, Rodrigues DP, dos Reis EM, Seki LM, Ribeiro AR, Fernandes SA. Phage types of Salmonella enteritidis isolated from clinical and food samples, and from broiler carcasses in southern Brazil. Revista do Instituto de Medicina Tropical de São Paulo 2003; 45(1):1-4.

Donoghue DJ. Antibiotic residues in poultry tissues and eggs: human health concerns? Poultry Sciences 2003; 82(4):618-621.

Fernandez A, Lara C, Loste A, Calvo S, Marca MC. Control of Salmonella enteritidis phage type 4 experimental infection by fosfomycin in newly hatched chicks. Comparative Immunology, Microbiology \& Infectious Diseases 2001; 24(4):207-216.

Flensburg J. Programs to control or eradicate Salmonella in animal production in Denmark. Acta Veterinaria Scandinavia 1999 (Suppl.); 91:51-58.

Gast RK, Holt PS. Persistence of Salmonella enteritidis from one day of age until maturity in experimentally infected layer chickens. Poultry Sciences 1998; 77(12):1759-1762.
Hayat MA. Principles and techniques of electron microscopy. Biological applications. 3ed. Boca Raton (FL): CRC Press Inc.; 1989.

Helms C, Dutchic JE, Olson MV. A lambda protocol based on purification of phage on DEAE cellulose. Methods of Enzymology $1987 ; 153: 69-82$

ICTV. The International Committee on Taxonomy of Viruses. http:/ /www.ncbi.nlm.nih.gov/ICTV/overview/dsdna.html. Accessed in October 2003.

Kinde H, Shivaprasad HL, Daft BM, Read DH, Ardans A, Breitmeyer R, Rajashekara G, Nagaraja KV, Gardner IA. Pathologic and bacteriologic findings in 27-week-old commercial laying hens experimentally infected with Salmonella enteritidis, phage type 4 . Avian Diseases 2000; 44(2):239-248.

Kudva IT, Jelacic S, Tarr PP, Youderian P, Hovne CJ. Biocontrol of Escherichia coli 0157 with 0157-Specific bacteriophages. Applied and Environmental Bacteriology 1999; 65:3767-3773.

Levine AJ. Viruses. Scientific American Library, New York. 1992. pp. $25-45$.

Mead PS, Slutsker L, Dietz V, McCaig LF, Bresee JS, Shapiro C, Griffin PM, Tauxe RV. Food-related illness and death in the United States. Emerging Infectious Diseases 1999; 5(5):607-625.

Molbak K, Gerner-Smidt P, Wegener HC. Increasing quinolone resistance in Salmonella enterica serotype Enteritidis. Emerging Infectious Diseases 2002; 8(5):514-515.

Molbak K, Neimann J. Risk factors for sporadic infection with Salmonella enteritidis, Denmark, 1997-1999. American Journal of Epidemiology 2002; 156(7):654-61.

Nayak R, Kenney PB, Keswani J, Ritz C. Isolation and characterization of Salmonella in a turkey production facility. British Poultry Sciences 2003; 44(2):192-202.

Paresi JTM, Almeida IAZC. Lima SI, Marques DF, Rodrigues ESA, Fernands AS, Gelli DS, Irino K. Surtos de enfermidades transmitidas por alimentos causados por Salmonella Enteritidis. Revista de Saúde Pública 1998; 32:477-483.

Persson $U$, Jendteg $S$. The economic impact of poultry-born salmonellosis: how much should be spent on prophylaxis? International Journal of Food Microbiology 1992; 15(3-4):207-213.

Rose BE, Hill WE, Umholtz R, Ransom GM, James WO. Testing for Salmonella in raw meat and poultry products collected at federally inspected establishments in the United States, 1998 through 2000. Journal of Food Protection 2002; 65(6):937-947.

Sambrook J, Fritsch EF, Maniatis T. Molecular cloning: a laboratory manual. 2ed. Cold Spring Harbor, NY, New York. 1989. p2.80.

Santos DMS, Berchieri Junior A, Fernandes AS, Tavechio AT, Amaral LA do. Salmonella em carcaças de frangos congeladas. Pesquisa Veterinária Brasileira 2000; 20:39-42.

Shivaprasad HL, Timoney JF, Morales S, Lucio B, Baker RC. 
Pathogenesis of Salmonella enteritidis infection in laying chickens. I. Studies on egg transmission, clinical signs, fecal shedding, and serologic responses. Avian Diseases 1990; 34(3):548-557.

Sklar IB, Joerger RD. Attempts to utilize bacteriophage to combat Salmonella enterica serovar Enteritidis infection in chickens. Journal of Food Safety 2001; 21:15-29.

Taunay AE, Fernandes AS, Tavechio AT, Neves BC, Dias AMG, Irino $K$. The role of public health laboratory in the problem of Salmonellosis in São Paulo, Brazil. Revista do Instituto de Medicina Tropical de São Paulo 1996; 38:119-127.

Tavechio AT, Ghilardi AC, Peresi JT, Fuzihara TO, Yonamine EK, Jakabi M, Fernandes SA. Salmonella serotypes isolated from nonhuman sources in São Paulo,Brazil, from 1996 through 2000. Journal of Food Protection 2002; 65(6):1041-1044.

Van Immerseel F, Cauwerts K, Devriese LA, Haesenbrouck F, Ducatelle R. Feed additives to control Salmonella in poultry. World's Poultry Science Journal 2002; 58:501-513.

Velonakis EN, Markogiannakis A, Kondili L, Varjioti E, Mahera Z, Dedouli E, Karaitianou A, Vakalis N, Bethimouti K. Evolution of antibiotic resistance of non-typhoidal salmonellae in Greece during 1990-97. Euro Surveillance 2001; 6(7):117-120.

Wegener HC, Hald T, Wong DL, Madsen M, Korsgaard H, Bager F, Gerner-Smidt P, Molbak K. Salmonella control programs in Denmark. Emerging Infectious Diseases 2003; 9(7):774-780.

Yamane Y, Leonard JD, Kobatake R, Awamura N, Toyota Y, Ohta $H$, Otsuki $K$, Inoue T. A case study on Salmonella enteritidis (SE) origin at three egg-laying farms and its control with an $\mathrm{S}$. enteritidis bacterin. Avian Diseases 2000; 44(3):519-526.

Zhang-Barber L, Turner AK, Barrow PA. Vaccination for control of Salmonella in poultry. Vaccine 1999; 17:2538-2545. 